NOTE

\title{
Climatic influence on reef fish recruitment and fisheries
}

\author{
Octavio Aburto-Oropeza ${ }^{1, *}$, Gustavo Paredes ${ }^{1}$, Ismael Mascareñas-Osorio ${ }^{2}$, \\ Enric Sala ${ }^{2,3}$ \\ ${ }^{1}$ Center for Marine Biodiversity and Conservation, Scripps Institution of Oceanography, 9500 Gilman Drive, La Jolla \\ California 92093-0202, USA \\ ${ }^{2}$ Centre d'Estudis Avançats de Blanes (CSIC), Blanes, Spain \\ ${ }^{3}$ National Geographic Society, Washington, DC, USA
}

\begin{abstract}
Interannual and interdecadal variability of the recruitment and spawning stock biomass of fish has been observed for many pelagic commercial species. For reef fish, climate variability has been considered only as a pre-recruitment factor that has stochastic impacts on the survival of eggs and larvae during their pelagic stage. Here we show that fisheries landings of reef fish are related to climatic conditions that occurred at the time of settlement. Using detailed studies on the life history of 2 important commercial species (yellow snapper and leopard grouper) and a compilation of landing statistics over $11 \mathrm{yr}$ in the Gulf of California, we established that increasing recruitment translated into greater fisheries landings and increased revenue once individuals recruited into fishery stocks. Recruitment appeared to be modulated by El Niño/La Niña events. Monitoring of reef fish recruitment could be used to adapt artisanal fisheries management ahead of time, allowing regulation of effort or setting of quotas based on the variability of climate indices.
\end{abstract}

KEY WORDS: Yellow snapper $\cdot$ Lutjanus $\cdot$ Leopard grouper $\cdot$ Mycteroperca $\cdot$ Fisheries revenue Multivariate ENSO index

\section{INTRODUCTION}

Climatic and oceanographic variability can cause fluctuations in the abundance of commercial fish stocks (Attrill \& Power 2002, Platt et al. 2003). Understanding the link between climatic change and these fluctuations could allow us to forecast the size of stocks and manage fisheries accordingly. However, the biological (e.g. growth rates, survivorship and mortality rates), ecological (e.g. reproduction frequency, distribution of spawning stocks) and oceanographic mechanisms (e.g. offshore advection, current gyres) (Hollowed et al. 2001, Williams et al. 2007) that explain fish abundance and how this abundance is reflected in fisheries catches are poorly understood.

We studied 2 important commercial reef fish in the Gulf of California, Mexico: the yellow snapper Lutjanus argentiventris and the leopard grouper Myctero- perca rosacea. The yellow snapper is a tropical species that originates from the Panamic province. It inhabits rocky bottoms down to at least $60 \mathrm{~m}$ depth and its distribution ranges from the Gulf of California to Peru. It grows up to $1 \mathrm{~m}$ in length and $10 \mathrm{~kg}$ in weight, reaches maturity after $3 \mathrm{yr}$, and can live up to $19 \mathrm{yr}$ (MartinezAndrade 2003). The leopard grouper is endemic to Mexico, and its distribution ranges from Bahía Magdalena on the Pacific coast of Baja California, throughout the Gulf of California from the northernmost rocky reefs at Roca Consag to southern Jalisco. This species grows up to $1.2 \mathrm{~m}$ in length and $18 \mathrm{~kg}$ in weight, reaches maturity after $3.5 \mathrm{yr}$, and can live up to $32 \mathrm{yr}$ (Aburto-Oropeza et al. 2008).

Both species have complex life cycles: they spawn around rocky islands (Sala et al. 2003), their larvae travel to and settle on shallow coastal habitats (yellow snapper in mangroves and leopard grouper in Sargas- 
sum beds), and juveniles travel to adult habitats over a 2 yr period. We monitored the abundance of these 2 species since 1998, and compiled fisheries landing statistics for the Gulf of California over $11 \mathrm{yr}$, to determine whether it is possible to predict fish recruitment and landings based on available a priori climate indices.

\section{MATERIALS AND METHODS}

Abundance of juveniles. To estimate interannual variation in yellow snapper and leopard grouper abundance, we surveyed 21 rocky reefs in the central and southern parts of the Gulf of California (AburtoOropeza et al. 2007). Data were collected every September from 1998 to 2008 by SCUBA divers using $50 \times$ $5 \mathrm{~m}$ line transects $\left(\mathrm{n}=4\right.$ to 6 replicate transects site ${ }^{-1}$ habitat $^{-1}$ ). All individuals belonging to different size classes in a visual range of $<2 \mathrm{~m}$ (Harmelin-Vivien et al. 1985) were counted. Total length (TL) of yellow snappers and leopard groupers was estimated in $5 \mathrm{~cm}$ intervals with the help of a PVC plastic tube. Divers swam along each transect at a constant speed, counting and estimating the size of all individuals within $2.5 \mathrm{~m}$ on either side of the transect line $\left(250 \mathrm{~m}^{2}\right.$ transect area). The authors were experienced at visually surveying fish assemblages and estimating fish lengths accurately (Sala et al. 2002).

Although we counted individuals of all sizes, we included only leopard grouper individuals with a total length of up to $15 \mathrm{~cm}$, since they were the young of the year. However, since young of the year for yellow snapper are present only inside mangroves, we used individuals with a total length between 15 and $25 \mathrm{~cm}$, which correspond to the smaller sizes that are seen in the rocky reefs and are individuals between 1.2 and 2.1 yr old (Aburto-Oropeza et al. 2009). We can then assume that these size classes of yellow snapper individuals are at the most 2 yr old after they settle.

Landings data. We considered landings data for the yellow snapper and the leopard grouper from the National Fisheries Commission (CONAPESCA) for the State of Baja California Sur, in the central southwest part of the Gulf of California. Records for the $400 \mathrm{~km}$ long stretch of the coast of Baja California Sur are publicly available by request. We worked with a database containing the fishing records from the town of Santa Rosalia and the city of La Paz. With the exception of the year 2004, landings were reported from 1999 to 2007. Although the statistics have specific categories, an important volume of the landings was registered as generic categories without species-specific information: 'pargos' (snappers), and 'cabrillas' (groupers). However, we calculated the proportions of these generic catches that are accounted for by our 2 target species, based on a previous study (Randall et al. 2005) which showed that yellow snapper and leopard grouper accounted for 40 and $90 \%$ of the 'snapper' and 'grouper' categories, respectively. The converted data were subsequently added to the species-level data to give the total landings of these 2 species along the coast of Baja California Sur.

To determine the size structure of the individuals that were caught in the region, we monitored 4 fishing cooperatives and 10 fishing towns from March 2007 to January 2009. Total length (to the nearest $\mathrm{mm}$ ) and weight (to the nearest $\mathrm{g}$ ) data were collected from yellow snappers and leopard groupers that were caught by artisanal fishers. To calculate the mean age of the catch, we used the mean size of the catch (Fig. 1) and

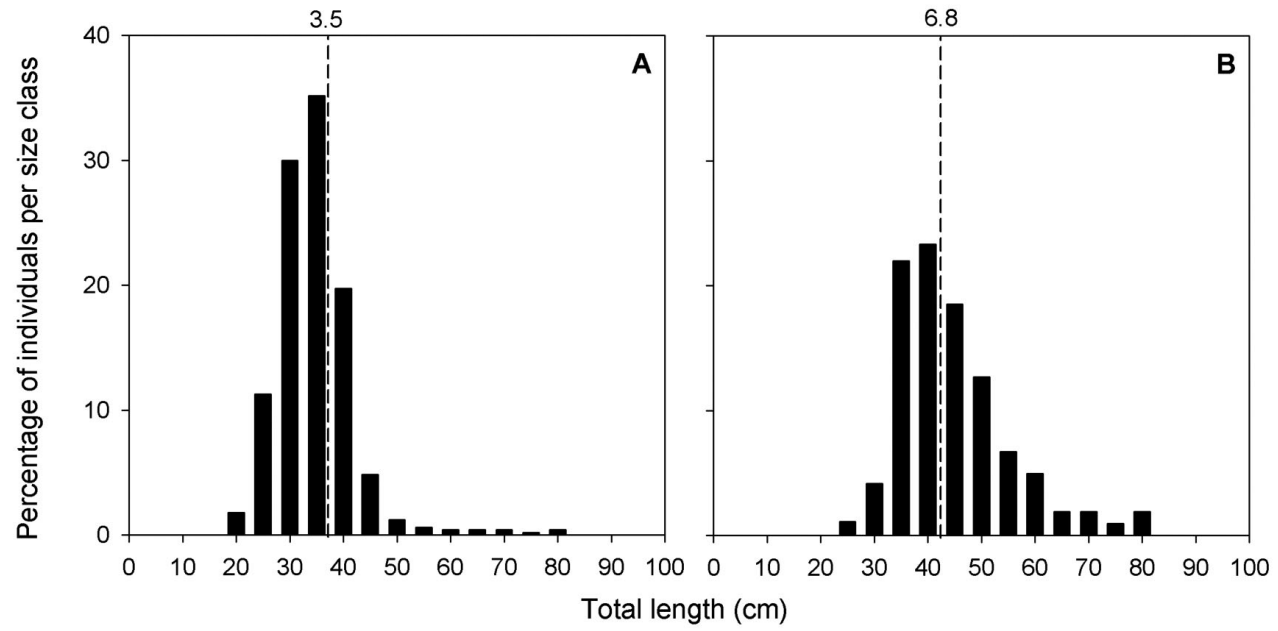

Fig. 1. Lutjanus argentiventris and Mycteroperca rosacea. Size-frequency distributions of collected $(\mathrm{A})$ yellow snappers $(\mathrm{n}=497)$ and (B) leopard groupers $(n=705)$ from fishery catches in the southern Gulf of California. Dashed lines are mean sizes and numbers above are the corresponding ages $(\mathrm{yr})$. Age was calculated using age at length zero $\left(t_{0}\right)$, asymptotic length $\left(L_{\infty}\right)$, and growth rate $(k)$ taken from the literature (Díaz-Uribe et al. 2001, Martinez-Andrade 2003) 
calculated the age of an individual within this size using the Bertalanffy growth model. For yellow snapper, the variables used (age at length zero $\left(t_{0}\right)$, asymptotic length $\left(L_{\infty}\right)$, and growth rate $\left.(k)\right)$ were obtained from Martinez-Andrade (2003); for leopard grouper, the variables were obtained from Díaz-Uribe et al. (2001).

The same CONAPESCA database included the amount of money that was paid for the catch $(\mathrm{kg})$ of yellow snapper and leopard grouper landed by fishermen in Santa Rosalia and La Paz in 1999 to 2003 and 2005 to 2007. Using these economic values, we calculated the increases in revenue between the best and the worst years in terms of fisheries landings.

Climate variability. We explored the relationship between the reef fish species and their fisheries using the Multivariate El Niño/Southern Oscillation (ENSO) Index (MEI; NOAA Cooperative Institute for Research in Environmental Sciences) as a measure of climate variability. MEI is a positive correlate of water temperature and a negative correlate of nutrient availability.
El Niño years (warmer, nutrient poor waters) are associated with strong positive values of MEI, whereas La Niña years (colder, nutrient-rich waters) are associated with strong negative values of this index. Bimonthly values for MEI are available from 1950 to the present (www.esrl.noaa. gov/psd/enso/).

\section{RESULTS AND DISCUSSION}

The MEI, which is a positive correlate of water temperature and a negative correlate of nutrient availability in the Pacific Ocean, explained the abundance of juveniles and fisheries landings (Fig. 2) for the yellow snapper (Fig. 2A, $\mathrm{p}=0.024, \mathrm{R}^{2}=0.45$; Fig. $2 \mathrm{~B}, \mathrm{p}=$ 0.033, $\mathrm{R}^{2}=0.56$ ) and the leopard grouper (Fig. $2 \mathrm{C}, \mathrm{p}<$ $0.001, R^{2}=0.88$; Fig. 2D, $p=0.041, R^{2}=0.53$ ). For both species, years with higher abundance of juveniles translated into greater fisheries landings once individuals recruited into fishery stocks (the average age of the yellow snapper and leopard grouper from fishing
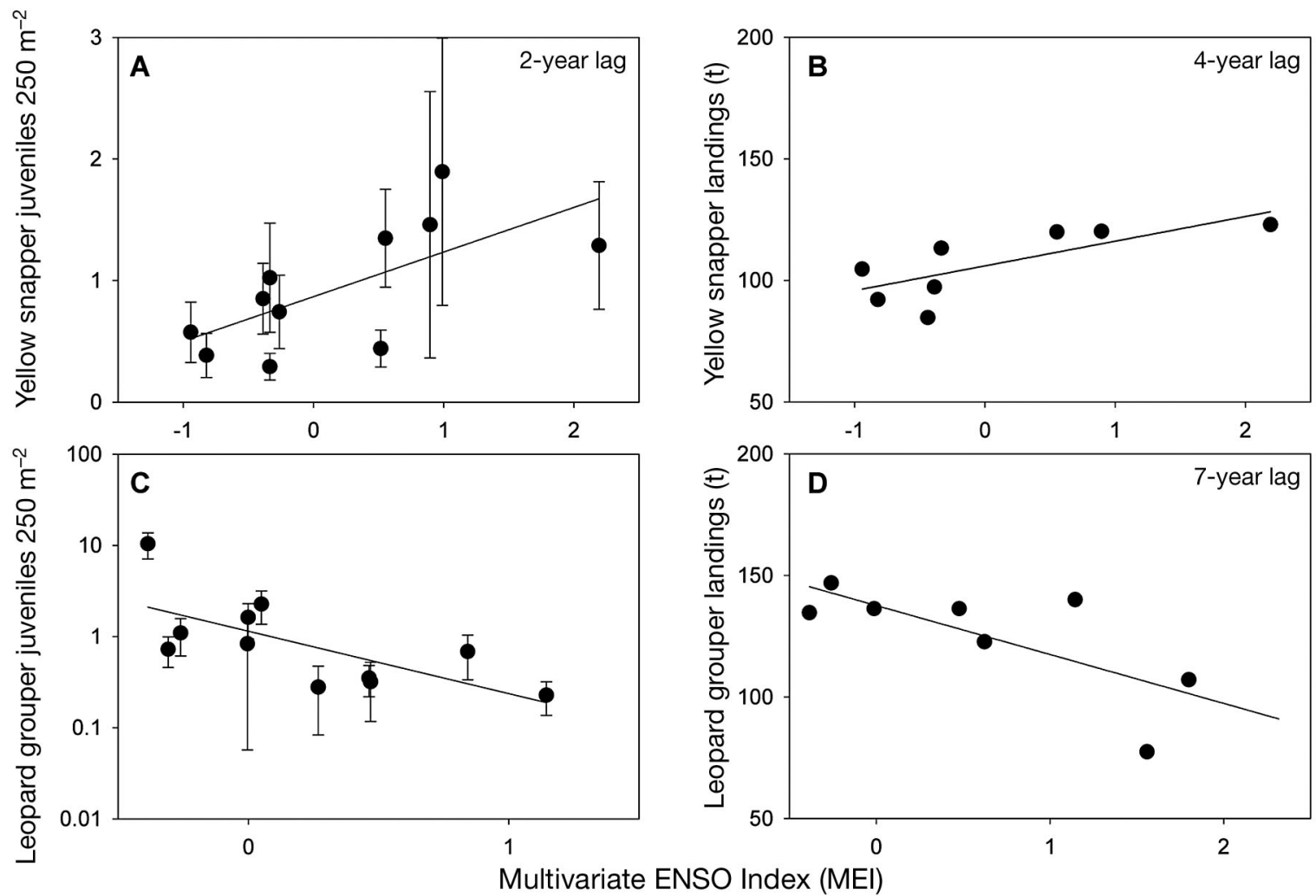

Fig. 2. Lutjanus argentiventris and Mycteroperca rosacea. Relationships of juvenile abundance (mean \pm SE) and landings in the Gulf of California with the multivariate ENSO index (MEI). Each point represents the annual average of juvenile abundance estimated using underwater surveys (note the log scale for leopard grouper in panel C), and the annual average of landings recorded in the official fisheries statistics. We used a time lag in the MEI for the yellow snapper juvenile abundance since surveys were conducted outside the settlement habitat (Aburto-Oropeza et al. 2009), and for the landings of both species because individuals recruit to the fishery several years after their nursery stage (Fig. 1). Regression lines for juvenile abundance and landings are as follows: $(A)$ abundance $=0.8670+0.3672 \mathrm{MEI}\left(\mathrm{p}=0.024, \mathrm{R}^{2}=0.45\right) ;(\mathrm{B})$ landings $=105.9584+10.1548 \mathrm{MEI}\left(\mathrm{p}=0.033, \mathrm{R}^{2}=0.56\right)$;

(C) abundance $=0.0001 \mathrm{e}^{-29.3147 \mathrm{MEI}}\left(\mathrm{p}<0.001, \mathrm{R}^{2}=0.88\right)$; and (D) landings $=137.6180-20.1253 \mathrm{MEI}\left(\mathrm{p}=0.041, \mathrm{R}^{2}=0.53\right)$ 
catches is 4 and 7 yr, respectively; Fig. 1). Years with higher abundance of juveniles can be predicted based on MEI values at the time of settlement; we used MEI values from September-October for the yellow snapper (Aburto-Oropeza et al. 2009) and from May-June for the leopard grouper (Aburto-Oropeza et al. 2007).

After yellow snapper larvae settle in mangroves, juveniles move to shallow rocky habitats where they mature. Adults then move to deep rocky reefs (AburtoOropeza et al. 2009). The abundance of yellow snappers in rocky islands and in fisheries catches increased with increasing MEI at 2 and 4 yr post-settlement respectively (Fig. 2A,B). In contrast to the yellow snapper, leopard grouper larvae settle in shallow Sargassum seaweed beds in rocky coasts and move to deeper habitats as they grow. Because the seasonal nursery habitat (Sargassum beds) is virtually nonexistent in warmer, nutrient-poor years (Aburto-Oropeza et al. 2007), recruitment of the leopard grouper decreased exponentially with increasing MEI (Fig. 1C; plotted on a log scale). Leopard grouper landings were significantly correlated with MEI values with a 7 yr time lag (Fig. 1D).

Recruitment appeared to be modulated by El Niño/ La Niña events, as has been observed for algal beds (Pacheco-Ruíz et al. 2003), small pelagic fishes (Sánchez-Velaso et al. 2000), and sea bird populations (Velarde et al. 2004) in the region. Colder La Niña years that are characterized by high nutrient concentrations in seawater enhance algal growth (Dayton et al. 1992, 1999) with a consequent increase in leopard grouper recruitment. During warm El Niño years, rainfall dramatically increases in the region (Holmgren et al. 2001), increasing nutrient concentrations inside mangrove estuarine habitats and hence yellow snapper recruitment. Analogous examples could be the sciaenid species (the corvinas Totoaba macdonaldi and Cynoscion othonopterus) that spawn and recruit in the Colorado River estuary (Flanagan \& Hendrickson 1976); their populations increased during years with more rainfall (Rowell et al. 2005, 2008). Although the mechanisms are not very clear, subsidies from land to the ocean during the warm/cold decadal periods seem to influence entire food webs (Polis et al. 1997) and have a positive effect on the fitness of individuals. In the case of other corvinas that were affected by ENSO events (Williams et al. 2007), juveniles grew at significantly different rates, and these differences appeared to be related to water temperature variations and food supply. The mechanisms underlying this population increase may include enhanced larval transport, enhanced local reproductive success, or improved larval and juvenile survival.

Fisheries of yellow snapper and leopard grouper represent an important income for several hundred fishers in the region. During 'good fishing years', fishing revenue increased from a conservative estimate of US\$ 70000 to US\$270000 and US\$ 370000 for yellow snapper and leopard grouper respectively. Predicting the magnitude of fisheries catches based on environmental variables is relatively straightforward when the time lag between the former and the latter is only a few months (e.g. pelagic migratory species such as sardines [Velarde et al. 2004], or mackerels [Arcos et al. 2001]). For species with complex life cycles that include ontogenetic habitat shifts that last for years, predicting abundance and catch years in advance is more problematic. The present study, however, shows that standard underwater visual surveys, combined with traditional fisheries statistics, can provide a methodology to predict fluctuations in abundance over time. More importantly, such simple measurements could be used to adapt artisanal fisheries management ahead of time, allowing regulation of effort or setting of quotas based on expected climate-mediated recruitment of fish into adult populations.

Acknowledgements. We thank J. Cota, A. Mendoza, T. Plomozo, C. Sánchez and C. Viesca for field assistance, and N. Holland, P. Hull, J. Jackson and C. Lopez for improving previous versions of the manuscript. This work was supported by the David and Lucille Packard Foundation, the Moore Family Foundation, and the Walton Family Foundation.

\section{LITERATURE CITED}

Aburto-Oropeza O, Sala E, Paredes G, Mendoza A, Ballesteros E (2007) Predictability of reef fish recruitment in a highly variable nursery habitat. Ecology 88:2220-2228

Aburto-Oropeza O, Erisman B, Váldez-Ornelas V, Danemann G (2008) Commercially important serranid fishes from the Gulf of California: ecology, fisheries, and conservation. Ciencia Marina y Conservación 1:1-44

Aburto-Oropeza O, Dominguez-Guerrero I, Cota-Nieto J, Plomozo-Lugo T (2009) Recruitment and ontogenetic habitat shifts of the yellow snapper (Lutjanus argentiventris) in the Gulf of California. Mar Biol 156:2461-2472

Arcos D, Cubillos L, Nunñez S (2001) The jack mackerel fishery and El Niño 1997-1998 effects off Chile. Prog Oceanogr 49:597-617

Attrill MJ, Power M (2002) Climatic influence on a marine fish assemblage. Nature 417:275?278

> Dayton PK, Tegner MJ, Parnell PE, Edwards PB (1992) Temporal and spatial patterns of disturbance and recovery in a kelp forest community. Ecol Monogr 62:421-445

> Dayton PK, Tegner MJ, Edwards PB, Riser KL (1999) Temporal and spatial scales of kelp demography: the role of oceanographic climate. Ecol Monogr 69:219-250

Díaz-Uribe FG, Elorduy-Garay JF, González-Valdovinos MT (2001) Age and growth of the leopard grouper, Mycteroperca rosacea, in the southern Gulf of California, México. Pac Sci 55:171-182

Flanagan CA, Hendrickson JR (1976) Observations on the commercial fishery and reproductive biology of Totoaba, Cynoscion macdonaldi, in the northern Gulf of California. Fish Bull 74:531-544 
Harmelin-Vivien ML, Harmelin JG, Chauvet C, Duval C and others (1985) Evaluation visuelle des peuplements et populations de poissons: méthodes et problèmes. Rev Ecol Terre Vie 40:467-539

Hollowed AB, Hare SR, Wooster WS (2001) Pacific basin climate variability and patterns of northeast Pacific marine fish production. Prog Oceanogr 49:257-282

Holmgren M, Scheffer M, Ezcurra E, Gutierrez JR, Mohren GMJ (2001) El Niño effects on the dynamics of terrestrial ecosystems. Trends Ecol Evol 16:89-94

Martinez-Andrade F (2003) A comparison of life histories and ecological aspects among snappers. PhD dissertation, Lousiana State University, Baton Rouge, LA

Pacheco-Ruíz I, Becerril-Bobadilla F, Zertuche-Gonzalez JA, Chee Barragan A, Galvez-Telles A, Blanco-Betancourt R (2003) Effects of El Niño on beds of Ulva lactuca along the northwest coast of the Gulf of California, Mexico. Geofis Int 42:447-453

Platt T, Fuentes-Yaco C, Frank KT (2003) Spring algal bloom and larval fish survival. Nature 423:398-399

Polis G, Hurd S, Jackson C, Piñero F (1997) El Niño effects on the dynamics and control of an island ecosystem in the Gulf of California. Ecology 78:1884-1897

Randall A, Thiriet P, Torre J, Sáenz-Arroyo A (2005) Impacto en la composición de peces de los arrecifes rocosos en el Parque Nacional Bahía de Loreto con dos métodos de pesca: piola y red de cerco. Poster presented at the Simpo-

Editorial responsibility: Tim McClanahan, Mombasa, Kenya sio sobre Ciencias Pesqueras en México, La Paz Baja California Sur, México, 2-4 May 2005

Rowell K, Flessa K, Dettman D, Roman M (2005) The importance of Colorado River flow to nursery habitats of the Gulf corvina (Cynoscion othonopterus). Can J Fish Aquat Sci 62:2874-2885

Rowell K, Flessa K, Dettman D, Roman M (2008) Diverting the Colorado River leads to a dramatic life history shift in an endangered marine fish. Biol Conserv 141:1138-1148

Sala E, Aburto-Oropeza O, Paredes G, Parra I, Barrera JC, Dayton PK (2002) A general model for designing networks of marine reserves. Science 298:1991-1993

Sala E, Aburto-Oropeza O, Paredes G (2003) Spawning aggregations and reproductive behavior of reef fishes in the Gulf of California. Bull Mar Sci 72:103-121

Sánchez-Velaso L, Shirasago B, Cisneros-Mata MA, AvalosGarcia C (2000) Spatial distribution of small pelagic fish larvae in the Gulf of California and its relation to the El Niño 1997-1998. J Plankton Res 22:1611-1618

> Velarde E, Ezcurra E, Cisneros-Mata MA, Lavín MF (2004) Seabird ecology, El Niño anomalies, and prediction of sardine fisheries in the Gulf of California. Ecol Appl 14: $607-615$

Williams JP, Allen LG, Steele MA, Pondella DJ II (2007) El Niño/Southern Oscillation events increase growth of juvenile white seabass (Atractoscion nobilis) in the Southern California Bight. Mar Biol 152:193-200

Submitted: January 28, 2010; Accepted: June 4, 2010 Proofs received from author(s): July 4, 2010 